\title{
Effect of Bullying on the Risk of Anxiety and Social Interaction Disorder among Senior High School in Yogyakarta
}

\author{
Hainas Sani Privetera1), RB. Soemanto'), Hanung Prasetya3) \\ 1)Masters Program in Public Health, Universitas Sebelas Maret \\ 2)Faculty of Social and Political Sciences, Universitas Sebelas Maret \\ 3)Study Program of Acupuncture, Health Polytechnics Ministry of Health Surakarta
}

\section{ABSTRACT}

Background: Bullying is a widespread phenomenon among young people and is used to describe interpersonal relationships characterized by an imbalance of power. The Indonesian Child Protection Commission noted that there were 161 cases of bullying in 2018. Adolescents who are involved in bullying experience risks such as psychiatric symptoms, alcohol and drug abuse and even suicide. This study aims to analyze the effects of bullying on selfconcept and social disorders in high school students in Sleman Yogyakarta.

Subjects and Method: This study used a cross sectional study design. This study was conducted in Sleman Regency in August 2019. The sample was taken by using stratified random sampling with a total of 200 senior high school students. The independent variables include parental education, social environment, anxiety level, self-concept, and social interaction disorders. The dependent variable was bullying behavior. Data were collected using a questionnaire. Data were analyzed by using multilevel multiple logistic regression with stata 13.

Results: Low family education $(b=3.11 ; 95 \%$ $\mathrm{CI}=0.83$ to $3.67 ; \mathrm{p}=0.002$ ), social environment in the city $(b=3.15 ; 95 \% \mathrm{CI}=0.71$ to 3.09 ; $\mathrm{p}=0.002)$, have social media $(\mathrm{b}=4.13 ; 95 \% \mathrm{CI}=$ 1.46 to $3.83 ; \mathrm{p}=0.000$ ), have a level of anxiety $(b=2.92 ; 95 \% \mathrm{CI}=0.62$ to $3.17 ; \mathrm{p}=0.005)$, negative self-concept $(\mathrm{b}=2.83 ; 95 \% \mathrm{CI}=0.62$ to $3.40 ; \mathrm{p}=0.005)$, social interaction disorder $(\mathrm{b}=$ $3.23 ; 95 \% \mathrm{CI}=0.87$ to $3.55 ; \mathrm{p}=0.001$ ) increased the likelihood of experiencing bullying in adolescents. Variations at the school level indicated that there was a contextual influence on bullying behavior (ICC $=13.18 \%$ ).

Conclusion: There is a statistically significant influence of parental education, social environment, social media, anxiety levels, self-concept, and social interaction disorders on bullying behavior in adolescents. Variations at the level of school show that there is a contextual influence on bullying behavior in adolescents.

Keywords: bullying, adolescents, multilevel analysis

\section{Correspondence:}

Hainas Sani Privetera. Masters Program in Public Health, Universitas Sebelas Maret. Jl. Ir. Sutami 36A, Surakarta 57126, Central Java. Email: sariprivitera@gmail.com. Mobile: +6282328848001.

Cite this as:

Privetera HS, Soemanto RB, Prasetya H (2020). Effect of Bullying on the Risk of Anxiety and Social Interaction Disorder among Senior High School in Yogyakarta. J Health Promote Behav. 05(04): 306-316. https://doi.org/10.26911/thejhpb.2020.05.04.08.

(i) (1) Journal of Health Promotion and Behavioris licensed under a Creative Commons cc)

\section{BACKGROUND}

Bullying is an act of violence that is done repeatedly and involves physical strength between the victim and the perpetrator. The incidence of bullying from year to year shows adisconcerting number. Bullying includes predominantly aggressive behavior and causes damage or pressure, physical or verbal aggression. Bullying causes psychological, physical, and emotional 
Privetera et al./ Effect of Bullying on the Risk of Anxiety and Social Interaction Disorder

symptoms (Erick et al., 2014; Liu and Graves, 2011).

D.I Yogyakarta Province has a prevalence rate above the national level, which is 8.1\%. Based on the results of the D.I Yogyakarta Province Basic Health Research in 2013, it is stated that mental emotional disorders in people aged 15 years old and over have a high prevalence, namely $11.4 \%$ (Ministry of Health, 2016). This bullying incident is also rife among youth in Yogyakarta City. The results of a survey conducted from July to August 2013 to 739 high school students in Yogyakarta City showed that 396 students (54\%) claimed to have seen bullying in the school environment and 100 students (13\%) had experienced bullying.

Bullying creates serious psychosocial risks and academic adjustment for both victims and perpetrators. In addition, there is evidence that people who only witness bullying can also be negatively affected. Adolescents who engage in bullying experience risks such as psychiatric symptoms, alcohol and drug abuse and even suicide (Kowalski and Limber, 2013; Wolke, 2017).

Bullying behavior in students can be influenced by high exposure through social media, family and peer environments, anxiety levels, low self-concept, social interaction disorders, so that children have the potential to become more aggressive, brave, rebellious, and seek social support for bullying to schoolmates whom they deem weak and easy to bully. The self-concept that exists in victims of bullying will develop from social interactions in their environment (Festl and Quandt, 2013; Craig et al., 2020; Martinez-Monteagudo et al., 2020; Saiz et al., 2019).

Based on the background description above, the researchers are interested in conducting a research entitled The Effects of Bullying on Self-Concept and Social
Disorders in High School Students in Sleman Yogyakarta.

\section{SUBJECTS AND METHOD}

\section{Study Design}

This study used a cross sectional research design. The study was conducted in Sleman Regency, Yogyakarta in August 2019. The study was conducted in 25 schools in Sleman Regency.

\section{Population and Sample}

In this study, the number of population studied was high school/vocational/MA students in Sleman Regency in August 2019. This study used stratified random sampling technique to select students and schools in Sleman Regency. The subjects were 200 from 8 subjects in each level 2 unit (school).

\section{Study Variable}

The dependent variable is bullying behavior in adolescents. Independent variables include: parental education, social environment, social media, anxiety level, selfconcept, social interaction disorders and level 2 is school.

\section{Operational Definition of Variables}

Bullying is the aggressive and negative behavior of a group of students which is done repeatedly to show strength or power with the aim of hurting the target (victim) mentally or physically.

Parental Education is a level or stage of education taken by students, in an effort to develop physically and spiritually, or through a process of changing ways of thinking or behavior intellectually and emotionally.

Social Environment is an environment that can influence someone to take action and change behavior.

Social Media is an electronic media which is used as a means of communication and accessing a content. 
Level of Anxiety is a feeling that is general in nature, where a person feels fear or loses self-confidence with no clear reason or form.

Slef-concept is the result of students knowing how to assess themselves.

Social Interaction Disorders represents anxiety or concern in certain situations involving large numbers of people in public places. The measurement scale in the independent variable uses a continuous scale, because for the needs of data analysis, it is converted into a dichotomous scale.

\section{Study Instrument}

Data collection techniques were conducted by using primary and secondary data. Primary data were obtained using a questionnaire filled out by study subjects. Secondary data were obtained from the Sleman Regency Health Office and the Sleman Regency Education Office in the form of high school/vocational school/MA student data in Sleman Regency. The instrument used was a questionnaire.

\section{Data Analysis}

The univariate analysis was to analyze the frequency distribution and characteristics of the study subjects, while the bivariate

Table 1. The Characteristics of Study Subjects (continous data)

\begin{tabular}{lccccc} 
Table 1. The Characteristics of Study Subjects (continous data) \\
\hline \multicolumn{1}{c}{ Characteristics } & N & Mean & SD & Min. & Max. \\
\hline Age (Years old) & 200 & 15.98 & 0.87 & 14 & 19 \\
Grade (10-11) & 200 & 10.47 & 0.50 & 10 & 11 \\
\hline
\end{tabular}

Table 2. The Characteristics of Study Subjects(dichotomous data)

\begin{tabular}{lcc}
\hline \multicolumn{1}{c}{ Characteristics } & N & $\%$ \\
\hline Students Age & & \\
14-16 years old & 154 & 77.0 \\
17-19 years old & 46 & 23.0 \\
Grade & & \\
X (10) & 107 & 53.5 \\
XI (11) & 93 & 46.5 \\
Gender & & \\
Male & 125 & 62.5 \\
Female & 75 & 37.5 \\
\hline
\end{tabular}

analysis used the chi-square test and the calculation of the odds ratio (OR) with a 95\% confidence level (CI) to study the relationship between the incidence of bullying in adolescents and the independent variables. Multivariate analysis using logistic regression through a multilevel approach indicated by the Intra Class Correlation (ICC)value.

\section{Study Ethics}

Study ethics includes informed consent, anonymity, confidentiality and ethical clearance. Ethical clearance in this study was carried out at Dr. Moewardi Surakarta Hospital and was declared ethical based on decree number: 1148/HREC/XI/2019.

\section{RESULTS}

1. Characteristics of Study Subjects

Table 1 shows the measurements of 200 students with the characteristics of adolescent age had a mean $=15.98$ and $\mathrm{SD}=$ 0.87 with the lowest age of 14 years old and the highest was 19 years old. Class characteristics (10-11) had a mean $=10.43$ and $\mathrm{SD}=0.50$, with the lowest grade of 10 and the highest grade was 11.
Age (Years old)
10.47 
Privetera et al./ Effect of Bullying on the Risk of Anxiety and Social Interaction Disorder

Table 2 shows that most of the study subjects were 14-16 years old by 154 students (77\%) and 46 students (23\%) were 17-19 years old. Most of the students came from grade X (10) who were 107 students (53.5\%) and there were 93 students (56.5\%) came from grade XI (11). As well as most of

Table 3. Univariate analysis (continuous data)

\begin{tabular}{lccccc}
\hline \multicolumn{1}{c}{ Variable } & N & Mean & SD & Min. & Max. \\
\hline Level of anxiety & 200 & 71.10 & 16.67 & 30 & 100 \\
Self-concept & 200 & 69.63 & 13.54 & 30 & 100 \\
Social interaction disorders & 200 & 19.80 & 4.07 & 8 & 30 \\
Bullying & 200 & 14.22 & 4.86 & 4 & 24 \\
\hline
\end{tabular}

Table 3 shows the results of descriptive statistical tests on variables which include the number of study subjects, the mean, standard deviation, minimum and maximum values for measuring the dependent variable and the independent variable on a continuous scale. The mean described the mean value and the standard deviation (SD) describes the variation in the data. If the standard deviation (SD) value is smaller the male students by 125 students (62.5\%) and 75 students (37.5\%) were female.

\section{Univariate Analysis}

The univariate analysis included levels of anxiety, self-concept, social interaction disorders, and bullying behavior.

Table 4. Univariate analysis (dichotomous data)

\begin{tabular}{lcc}
\hline Variables & $\mathbf{N}$ & $\mathbf{\%}$ \\
\hline Bullying & 140 & 70.0 \\
No & 60 & 30.0 \\
Yes & & \\
Parental Education & 136 & 68.0 \\
High & 64 & 32.0 \\
Low & & \\
Social Environment & 141 & 70.5 \\
Village & 52 & 29.5 \\
City & & 68.5 \\
Social Media & 137 & 31.5 \\
No & 63 & 74.0 \\
Yes & & 26.0 \\
Level of Anxiety & 148 & 74.5 \\
Not anxious & 52 & 25.5 \\
Anxious & & \\
Self Concept & 149 & 71.5 \\
Positive & 51 & 28.5 \\
Negative & & \\
Social Interaction Disorders & 143 & \\
No & 57 & \\
Yes & & \\
\hline
\end{tabular}


Table 4 shows that most of the study subjects who were not experienced bullying (70.0\%), had high parental education (68.0\%), did not have social media (68.5\%), were not anxious (74.0\%), had positive selfconcept $(74.5 \%)$, and had no social interaction disorders (71.5\%).

Table 5. Bivariate analysis of the effect of parental education, social environment, social media, anxiety levels, self-concept, and social interaction disorders on bullying behavior in adolescents

\begin{tabular}{|c|c|c|c|c|c|c|}
\hline \multirow{3}{*}{ Variable Group } & \multicolumn{4}{|c|}{ Bullying } & \multirow{3}{*}{ OR } & \multirow{3}{*}{$\mathbf{p}$} \\
\hline & \multicolumn{2}{|c|}{ Yes } & \multicolumn{2}{|c|}{ No } & & \\
\hline & $\mathbf{n}$ & $\%$ & $\mathbf{n}$ & $\%$ & & \\
\hline Parental Education & & & & & 4.79 & $<0.001$ \\
\hline High & 26 & 19.1 & 110 & 80.9 & & \\
\hline Low & 34 & 53.1 & 30 & 46.9 & & \\
\hline Social Environment & & & & & 6.01 & $<0.001$ \\
\hline Village & 26 & 18.4 & 115 & 81.6 & & \\
\hline City & 34 & 61.0 & 25 & 39.0 & & \\
\hline Social Media & & & & & 11.57 & $<0.001$ \\
\hline No & 19 & 13.8 & 118 & 86.2 & & \\
\hline Yes & 41 & 65.0 & 22 & 35.0 & & \\
\hline Level of Anxiety & & & & & 6.05 & $<0.001$ \\
\hline Not anxious & 29 & 19.5 & 119 & 80.5 & & \\
\hline Anxious & 31 & 59.6 & 21 & 40.4 & & \\
\hline Self Concept & & & & & 6.41 & $<0.001$ \\
\hline Positive & 28 & 18.9 & 120 & 81.1 & & \\
\hline Negative & 31 & 60.7 & 20 & $39 \cdot 3$ & & \\
\hline Social Interaction Disorders & & & & & 12.58 & $<0.001$ \\
\hline No & 21 & 14.6 & 122 & 85.4 & & \\
\hline Yes & 39 & 65.0 & 21 & 35.0 & & \\
\hline
\end{tabular}

Table 5 shows the results of the chi-square test on the effect of parental education, social environment, social media, anxiety levels, self-concept, and social interaction disorders on bullying behavior.

a. The effect of parental education on bullying behavior in adolescents Low parental education increased the likelihood of experiencing bullying in adolescents. Adolescents with low parental education increase the likelihood of experiencing bullying in adolescents by 4.79 times higher than adolescents with high parental education $(\mathrm{OR}=4.79, \mathrm{p}<0.001)$.

b. The effect of social environment on bullying behavior in adolescents

\section{Bivariate Analysis}

Statistical analysis used to see the effect of a dependent variable (bullying behavior) on the independent variable (parental education, social environment, social media, anxiety level, self-concept, and social interaction disorders) in Table 5 . 


\section{d. The effect of anxiety level on bully- ing behavior in adolescents}

Adolescents who have anxiety increased the likelihood of experiencing bullying by 6.05 times higher than adolescents who are not anxious $(\mathrm{OR}=6.05, \mathrm{p}<0.001)$.

e. The effect of self concept on bullying behavior in adolescents

Adolescents with negative self-concepts increased the likelihood of experiencing bullying by 6.41 times higher than adolescents with positive self-concepts (OR=6.41, $\mathrm{p}<0.001)$.

f. The effect of social interaction disorders on bullying behavior in adolescents

Adolescents with social interaction disorders increase the likelihood of experiencing bullying in adolescents by 12.58 times higher than adolescents with no social interaction disorders $(\mathrm{OR}=12.58, \mathrm{p}$ $<0.001)$.

\section{Multivatiate Analysis}

Table 6 shows the results of a multilevel analysis of bullying behavior in adolescents using logistic regression with a multilevel approach. The results of the analysis can be described as follows:

\section{a. The effect of parental education on bullying behavior in adolescents}

There was a positive influence between parental education on bullying behavior in adolescents. Adolescents with low parental education have a risk (logodd) for experiencing bullying behavior by 3.11 units higher than adolescents with high parental education $(\mathrm{b}=3.11 ; 95 \% \mathrm{CI}=0.83$ to $3.67 ; \mathrm{p}=$ o.002).

b. The effect of social environment on bullying behavior in adolescents

There was a positive influence of social environment on bullying behavior in adolescents. Adolescents with social environments in cities have a risk (logodd) of experiencing bullying behavior by 3.15 units higher than adolescents with social environments in villages $(b=3.15 ; 95 \% \mathrm{CI}=0.71$ to $3.09 ; \mathrm{p}=0.002$ ).

c. The effect of social media on bullying behavior in adolescents

There was a positive influence of social media on bullying behavior in adolescents. Adolescents who owned social media have a risk (logodd) to experience bullying behavior by 4.13 units higher than adolescents who do not have social media $(b=4.13 ; 95 \%$ $\mathrm{CI}=1.46$ to $3.83 ; \mathrm{p}<0.001$ ).

d. The effect of anxiety level on bullying behavior in adolescents

There was a positive influence of the level of anxiety on bullying behavior in adolescents. Adolescents who were anxious have a risk (logodd) for experiencing bullying behavior by 2.92 units higher than adolescents who were not anxious $(b=2.92 ; 95 \%$ $\mathrm{CI}=0.62$ to $3.17 ; \mathrm{p}=0.005$ ).

e. The effect of self concept on bullying behavior in adolescents

There was a positive influence of self-concept on bullying behavior in adolescents. Adolescents with negative self-concept have a risk (logodd) to experience bullying behavior by 2.83 units higher than adolescents with positive self-concept $(b=2.83 ; 95 \%$ $\mathrm{CI}=0.62$ to $3.40 ; \mathrm{p}=0.005$ ).

f. The effect of social interaction disorders on bullying behavior in adolescents

There was a positive influence of social interaction disorders on bullying behavior in adolescents. Adolescents with social interaction disorders have a risk (logodd) for experiencing bullying behavior by 3.23 units higher than adolescents with no social interaction disorders $(b=3.23 ; 95 \% \mathrm{CI}=$ 0.87 to $3.55 ; p=0.001$ ).

g. The effect of school on bullying behavior in adolescents

The school level showed that there was a contextual influence on bullying behavior 
in adolescents $(\mathrm{ICC}=13.18 \%)$. The variation of bullying behavior among adolescents was $13.18 \%$ influenced by school. Table 6 showed that the ICC score in this study was

Table 6. The results of multilevel multiple logistic regression analysis of the effect of parental education, social environment, social media, anxiety levels, selfconcept, social interaction disorders on bullying behavior in adolescents

\begin{tabular}{|c|c|c|c|c|}
\hline \multirow[b]{2}{*}{ Independent Variables } & \multirow[b]{2}{*}{ b } & \multicolumn{2}{|c|}{$95 \% \mathrm{CI}$} & \multirow[b]{2}{*}{$\mathbf{p}$} \\
\hline & & Lower Limit & $\begin{array}{l}\text { Upper } \\
\text { Limit }\end{array}$ & \\
\hline \multicolumn{5}{|l|}{ Fixed Effect } \\
\hline Parental education (low) & 3.11 & 0.83 & 3.67 & 0.002 \\
\hline Social environment (city) & 3.15 & 0.71 & 3.09 & 0.002 \\
\hline Social Media (yes) & 4.13 & 1.36 & 3.83 & 0.000 \\
\hline Level of anxiety (high) & 2.91 & 0.62 & 3.17 & 0.004 \\
\hline Self concept (negative) & 2.83 & 0.62 & 3.40 & 0.005 \\
\hline Social interaction disorders (yes) & 3.23 & 0.87 & 3.55 & 0.001 \\
\hline \multicolumn{5}{|l|}{ Random effect } \\
\hline School Variable & 0.49 & & & \\
\hline $\mathrm{N}$ observation $=200$ & & & & \\
\hline $\mathrm{N}$ group $=25$ & & & & \\
\hline Group average $=8, \min =8, \max =8$ & & & & \\
\hline Log likelihood $=-51.85$ & & & & \\
\hline $\mathrm{p}=0.000$ & & & & \\
\hline p LR test vs logistic regression $=0.232$ & & & & \\
\hline $\mathrm{ICC}=13.18 \%$ & & & & \\
\hline
\end{tabular}

\section{DISCUSSION}

1. The effect of parental education on bullying behavior in adolescents

Parental education will affect children's growth and development because the parents' backgrounds will shape their mindset in educating their children. Parental education will influence the parenting style applied to their children. Parenting style will determine child's behavior, including bullying. Each parenting style can have the potential to influence bullying behavior (Xantus et al., 2015).

Parents with high education will have better knowledge in caring for their children, parents with higher education will be able to adjust parenting styles according to the psychological condition of their children. Parental education can influence the mindset of parents, which then affects the aspirations or hopes of their children, inclu- greater than the $8-10 \%$ rule of thumb, so the contextual influence in this study was that school was very important to note. ding the aspirations or expectations of their children's behavior. Parents' expectations for their child's behavior will affect the parenting style that will be applied (OrtegaBaron et al., 2015; Marcillo et al., 2016).

\section{The effect of social environment on bullying behavior in adolescents}

Festl and Quandt (2013) reported that the social environment affects the incidence of bullying behavior. The social environment of the group members of bullying perpetrators or victims is characterized by a high and centered social position in school. They are liked socially by their schoolmates. Children's behavior and morals are also influenced by environmental factors outside of school. Both factors from the family environment and factors from the surrounding environment or the surrounding community environment (Marcillo et al., 2016). 
The social environment is an important factor in the psychological formation and social norms of a person in society. There can be interactions in the social environment between the community and the environment, or the environment which also consists of social or human beings. This community environment then forms a social system that has a major role in shaping a person's personality, then there is an interaction between people or society with their environment. For example, environment where living conditions are used to violence, an environment where bullying is prone to occur (Maunder and Crafter, 2018).

\section{The effect of social media on bully- ing behavior in adolescents}

Easy access to social media and widespread use of social media can create new opportunities for bullying through cyberspace. Social media can display content that triggers bullying behavior such as videos, photos, messages sent via social media, or violent films. Adolescents who own social media can access these content, whether intentionally or unintentionally (Craig et al., 2020: Garett et al., 2016).

Bullying on social media can occur when misunderstandings arise, information or rumors are taken out of context, or if there is an intention to harm by comments or rumors that have negative intention, broadcasts on social media are not good. Every broadcast and news published in both print and electronic media has a different impact on each individual. For example, shows or news that broadcasts about violence can serve as an example for students to engage in bullying behavior wherever they are (Pradaz et al., 2017; Notar et al., 2013).

\section{The effect of anxiety level on bully- ing behavior in adolescents}

This study is also in line with Xantus et al., (2015) which stated that a person's anxiety level greatly influences bullying behavior. It's important to mention that adolescents with early symptoms of anxiety or depression may be more likely to view situations in negative way than adolescents without anxiety or depression. The presence of anxiety or depressive symptoms can cause a person to do something good or bad.

This is in line with Martinez-Monteagudo et al., (2020) showing that groups with high scores and greater social anxiety show adolescents who are more intensely involved in bullying behavior and who are more depressed, socially uncomfortable, and are more likely to avoid most of the social situations which they should have associated with peers. Typical social anxiety behaviors can have long-term repercussions as well as potentially causing social interaction problems, inhibiting social behavior with peers in real life environments (Saiz et al., 2019).

\section{The effect of self concept on bully- ing behavior in adolescents}

This is in line with Festl and Quandt (2013) which states that self-concept is one of the occurrences of bullying behavior. Bullies are usually more diligent, more extraverted, but less conscientious and pleasant, while victims are more diligent, as well as uncertain and reserved. Perpetrators or victims seem to usually have a special group. Their personality characteristics are more similar to those of bullies and also different from those of pure victims: They are highly extroverted people, who tend to be quick to criticize others.

Bullying usually occurs when someone with a low self-concept, one of them feels low self-esteem with other friends. If a person has low self-esteem, he will commit bullying which, if not addressed, will 
experience mental health problems and experience public health problems (Xantus et al., 2015; Albuhairan et al., 2017).

Karatas and Ozturk (2011) shows that the impact of bullying that occurs on victims of bullying can experience far more symptoms than the perpetrators of bullying. The association between exposure to bullying and health problems was found that children who were victims of bullying had high scores of having headaches, feeling bad, crying, dizziness, restlessness, nervousness, sleep problems much more frequently. It has been detected in studies that children who are victims of bullying have more health and mental problems than children who do not engage in bullying (Saiz et al., 2019).

\section{The effect of social interaction dis- orders on bullying behavior in adolescents}

In line with the research of Saiz et al., (2019) which shows that adolescents who do not experience bullying have no social interaction disorders in the school environment. Adolescents who have social interaction disorders such as closing themselves more, blaming themselves, feeling inferior, feeling intimidated, feeling guilty have no place in the bully's mind when he causes pain, harm and injury to the victim, thus making someone more happy to be alone and it possibly becomes the strongest predictor of bullying. Feelings of inferiority are a strong motive shown by bullies (Almahasnih, 2019).

Someone who performs bullying usually has social interaction disorders, anxiety disorders, or other psychological disorders. Bullying is a problem that affects not only the bully and the victim, but all students in the school. It causes headaches, feeling unwell, crying, dizziness, restlessness, nervousness, sleep problems and poor appetite experienced by children signifi- cantly more frequently. Children exposed to high levels of bullying experience more problems than their peers(Karatas and Ozturk, 2011).

\section{The effect of school on bullying behavior in adolescents}

School is a place of education that can be said to be successful if it is able to change children's behavior for the better. Many students did not report the bullying they experienced to the teacher. This is because there is a threat from the bullies. In addition, the majority of teachers also consider bullying to be a common thing between children while playing and part of a child's maturation process. The understanding of bullying in schools has not been fully realized and they do not consider bullying as behavior that is against social norms (Maunder and Crafter, 2018).

Children spend a lot of time at school, so the bullying that occurs can be caused by school conditions. The tendency of schools to often ignore the existence of bullying makes students who are bullies increasingly getting reinforcement of this behavior. In addition, bullying can occur in schools if the supervision and ethical guidance of teachers is low, schools with very rigid discipline, inappropriate guidance and inconsistent regulations. The type of bullying most often done by adolescents is verbal aggression, especially mentioning and spreading the name of rumors (Brito and Oliviera, 2013; Albuhairan et al., 2017).

Based on the results of the study, it can be concluded that there is a significant influence between parental education, social environment, social media, anxiety levels, self-concept, and social interaction disorders on bullying behavior in adolescents. Variations at the school level indicate that there is a contextual influence on the incidence of bullying in adolescents. 
Privetera et al./ Effect of Bullying on the Risk of Anxiety and Social Interaction Disorder

\begin{abstract}
AUTHOR CONTRIBUTION
Hainas Sani Privetera as the main researcher has roles in coordinating the study, conducting all stages of the study, and completing the study paper. Bhisma Murti played a role in compiling the study framework, processing the data, presenting the results of study analysis, and preparing study papers. Soemanto and Hanung Prasetya have roles in developing ideas, study designs, and study hypotheses.
\end{abstract}

\section{CONFLICT OF INTEREST}

There was no conflict of interest in this study.

\section{FUNDING AND SPONSORSHIP}

This study is self-funded.

\section{ACKNOWLEDGEMENT}

Our gratitude goes to all school principals and teachers of HS/VS/MA in Sleman Regency who has helped this study and also students who have been willing to become study subjects.

\section{REFERENCE}

Albuhairan F, Abbas OA, Sayyed DE, Badri M, Alshahri S, Vries ND (2017). The relationship of bullying and physical violence to mental health and academic performance: A cross-sectional study among adolescents in Kingdom of Saudi Arabia. Int J Pediatr Adolesc Med. 4(2): 61-65. http://dx.doi.org/10.1016/j.ijpam.2016.12.005.

Almahasnih AFS (2019). The phenomenon of bullying: A case study of Jordanian Schools at Tafila. World Journal of Education. 9(1). https://doi.org/10.5430/wje.v9n1p243.

Brito CC, Oliveira MT (2013). Bullying and self-esteem in adolescents from public schools. J Pediatr (Rio J). 89(6): 601-
607. http://dx.doi.org/10.1016/j.jped.2013.04.001.

Craig W, Boniel-Nissim M, King N, Walsh SD, Boer M, Donnelly PD, Harel-Fisch $Y$, et al. (2020). Social media use and cyber-bullying: A cross-national analysis of young people in 42 countries. 66(6): S100-S108. J Adolesc Health. https://doi.org/10.1016/j.jadohealth. 2020.03.006.

Erick M, Kristi K, Juan C (2014). School bullying, cyberbullying, or both: correlates of teen suicidality in the 2011 CDC Youth Risk Behavior Survey. Compr Psychiatry. 55(5): 1063-8 https://doi.org/10.1016/j.comppsych. 2014.02.005.

Festl R, Quandt T (2013). Social relations and cyberbullying: The influence of individual and structural attributes on victimization and perpetration via the internet. Human Communication Research. 39(1): 101-126. https://doi.org/10.1111/j.1468-2958.2012.01442.X.

Garett R, Lord LR, Young SD (2016). Associations between social media and cyberbullying: A review of the literature. MHealth. 2(46). http://dx.doi.org/10.21037/mhealth.2016.12.01.

Liu J, Graves N (2011). Childhood bullying: A review of constructs, contexts, and nursing implications. Public Health Nurs. 6(3): 379-390. https://doi.org/10.1111/j.1525-1446.2011.00972.x.

Karatas H, Ozturk C (2011). Relationship between bullying and health problems in primary school children. Asian Nursing Research. 5(2): 81-87. https://doi.org/10.1016/S1976-1317(11)6o016-9.

Kemenkes (2016). Peran keluarga dukung kesehatan jiwa masyarakat. Available at: http://www.depkes.go.id/article/print/16100700005/peran-keluarga- 
Privetera et al./ Effect of Bullying on the Risk of Anxiety and Social Interaction Disorder

dukungkesehatan-jiwa-masyarakat.html (Accessed July 2019).

Kowalski RM, Limber SP (2013). Psychological, physical, and academic correlates of cyberbullying and traditional bullying. J Adolesc Health. 53(1): S13-S20. https://doi.org/10.1016/j.jadohealth.2012.09.018.

Marcillo C, Ramos-Olazagasti MA, Blanco C, Sala R, Canino G, Bird H, Duarte CS (2015). Socio-cultural context and bulling others in childhood. J Child Fam Stud. 24(8): 2241-2249. https://doi:10.1007/s10826-014-0026-1.

Martinez-Monteagudo MC, Delgado B, Ingles CJ, Escortell R (2020). Cyberbullying and social anxiety: A latent class analysis among Spanish adolescents. Int J Environmental Res Public Health. 17: 406. https://doi:10.3390/ijerph17020406.

Maunder R, Crafter S (2018). School bullying from a sociocultural perspective. Aggression and Violent Behavior. 38: 13-20. https://doi.org/10.1016/j.avb.2017.10.010.

Notar CE, Padgett S, Roden J (2013). Cyberbullying: A review of the literature. Universal Journal of Educational Research. 1(1): 1-9. DOI: 10.13189/ujer.2013.010101.

Ortega-Baron J, Buelga S, Cava MJ (2015). The influence of school and family environment on adolescent victims of cyberbullying. Comunicar Media Edu- cation Research Journal. https://www.revistacomunicar.com/index.php? contenido $=$ detalles\&numero $=46$ \&articulo=46-2016-o6\&idioma $=$ en .

Pradas ICL, Romera EM, Casas JA, Ruiz RO (2017). Cybergossip and cyberbullying during primary school years. Psicología Educativa. 23: 73-80. http://dx.doi.org/10.1016/j.pse.2017. 05.007.

Saiz MJS, Chacon RMF, Abejar MG, Parra MDS, Rubio MEL, Jimenez SY (2019). Personal and social factors which protect against bullying victimization. http://dx.doi.org/10.6018/eglobal.18. 2.345931.

Wolke D (2017). Prevalence and consequences of bullying: What could healthcare services do for intervention. European Psychiatry. 41: S25. https://doi:10.1016/j.eurpsy.2017.01.132.

Xantus A, Saltz SB, Shaw JA (2015). The relationship between social media bullying and the adolescent's self report of emotional health: A study of urban youth on an acute inpatient psychiatric unit. J Depress Anxiety. 4(2): 186. https://doi:10.4172/21671044.1000186. 